\title{
The Architectural and Interior Design Identity Crisis: The Case of Girne in North Cyprus
}

\author{
Yaman Sokienah
}

Faculty of Fine Arts, Yarmouk University, Irbid, Jordan

Received September 10, 2020; Revised October 29, 2020; Accepted December 20, 2020

\section{Cite This Paper in the following Citation Styles}

(a): [1] Yaman Sokienah, "The Architectural and Interior Design Identity Crisis: The Case of Girne in North Cyprus," Civil Engineering and Architecture, Vol. 9, No. 1, pp. 124-129, 2021. DOI: 10.13189/cea.2021.090110.

(b): Yaman Sokienah (2021). The Architectural and Interior Design Identity Crisis: The Case of Girne in North Cyprus. Civil Engineering and Architecture, 9(1), 124-129. DOI: 10.13189/cea.2021.090110.

Copyright $(2021$ by authors, all rights reserved. Authors agree that this article remains permanently open access under the terms of the Creative Commons Attribution License 4.0 International License

\begin{abstract}
This article discusses the effects of globalization on architecture and concentrates on a case study which is Girne-North Cyprus. It outlines globalization's impact on architecture and interior design in Girne, including the method in which the architecture is transformed in the process of globalization. This article shows the impact of the rapidly growing construction sector, particularly in the form of mass housing, in the carefully considered and natural re-identification and changing the meaning of places. The study has been limited to Girne's city as an example of what is happening in Northern Cyprus. The impact of globalization on the local built environment was investigated through reviewing the literature on the construction sector in North Cyprus. The problem of globalization's effects on identity in the world has become present significantly in Girne's city through the global architectural and design style that is being added to the urban, architectural, and interior design of the city. The development associated with globalization and its mechanisms contributed to bridging this gap. It can be concluded that the existing situation was mass housing and construction companies that are being introduced to the city will increase the urban growth and development of the Girne. However, this development will directly reflect on the architectural and urban form of the city negatively. If the same attitudes keep developing, even more, the city's identity will be lost.
\end{abstract}

Keywords Globalization, Architecture, Built Environment, Design Identity, Interior Design

\section{Introduction}

Any country's national identity is directly connected with its architecture and design style. The choices made through the politics and regulations will impact the country's architectural identity, and this impact can be observed in the changes that are being made to the architectural textile of its cities. Making decisions that affect and change a city's architectural and design identity has always been a controversial topic as if there is a need to follow the global trend or keep the architectural and design identity and heritage[1].

We live in a time where rapid urbanization is a dominant factor in shaping the cities we live in, and these changes are affecting cities as a whole, from infrastructure to the interior design of the city's buildings[2]. These days we can see how globalization extended around the world in the last several decades and has come to be an initial discussion and research subject in many articles, books, and conferences. Globalization has made a revelation in the world, and it has made changes in many aspects. Globalizations are creating a universal taste and acceptance of new things from all over the world, in terms of food, clothing, transportation, and constructing materials and shapes. Therefore, globalization has transformed all aspects of economic, political, society, social, and architecture[3].

People's lives are surrounded by culture, buildings, and urban life connected with the built environment and transportation system. Therefore, architecture is considered as the main component that reflects the civilization and development in a society. Over the last few centuries, 
architecture has developed since the industrial revolution started to change in the time of globalization[4].

At this time, we can see many architects working hard to be international architects by designing and building international buildings and using the same style worldwide. Using the international form in architecture, we can say that we will have a global unity, so the architects make many transformations on local architecture, like building skyscrapers and global cities. There are many examples of this transformation by architects like Peter Eisenman, Zaha Hadid, Rem Koolhaas, and global cities like New York, Toronto, Dubai, and Tokyo. Therefore, with a focus on architecture and interior design, there is an international understanding that architecture and design create each city's unique skyline. Its positivity or negativity impacts a city's architectural, interior design, and urban identity [5].

In this article, the impact of globalization on the architecture, interior design, and urban identity of GirneCyprus is being discussed by presenting previous research and generating general conclusion from the new architectural and interior design styles that are being introduced to the city, which may lead to the loss of the architectural identity of the city. This article aims to open up discussions on the future of architecture and interior design in Girne.

\section{Research Problem}

North Cyprus has experienced rapid growth in the construction industry during and after 2002 due to political developments and regulations (see Figure 1\&2)[6]. This growth brought several architectural and interior design styles through international construction companies. The research problem is to show how globalization is changing place identity into new forms. Identity is one of the essential aims for the future of a pleasant environment. People feel that some part of the environment belongs to them individually and communally, and some portions for which they care are responsible.



Figure 1. Buildings Constructed between 2000 and 2007[7].

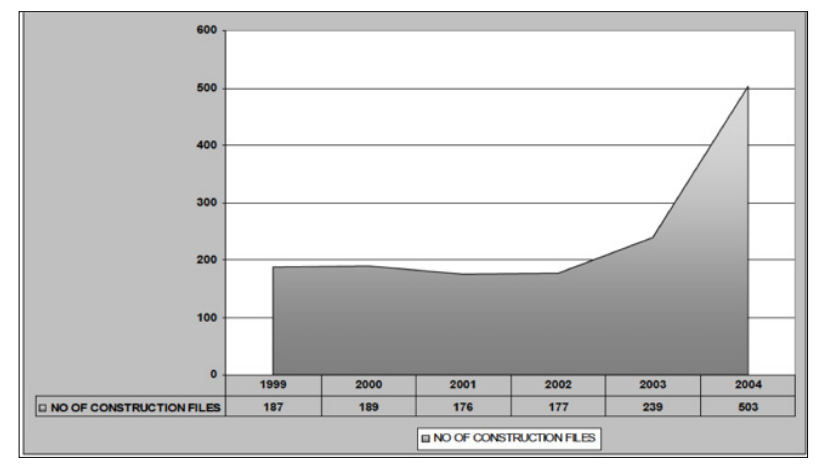

Figure 2. Housing construction in the Girne region per year[8].

Like other Middle East countries, Cyprus started to receive a significant inflow of international ideas that are different from its local architectural and design heritage. Middle East countries were interested in practicing Modernism, for it gave them a fresh visual start, Harmonious with these new mental patterns. Due to the increase in using international styles, the traditional architecture in north Cyprus is ignored and disregarded, leading to a significant design and urban identity crisis[9].

Girne's city attracts many foreign investors and construction companies to buy and develop the land into mass housing projects (see Figure 03)[8]. This attitude is consuming the land of the city and changing the design and urban identity of Girne. Therefore, this issue was studied to propose suggestions that would help conserve the architecture, interior design, and urban identity of the city.

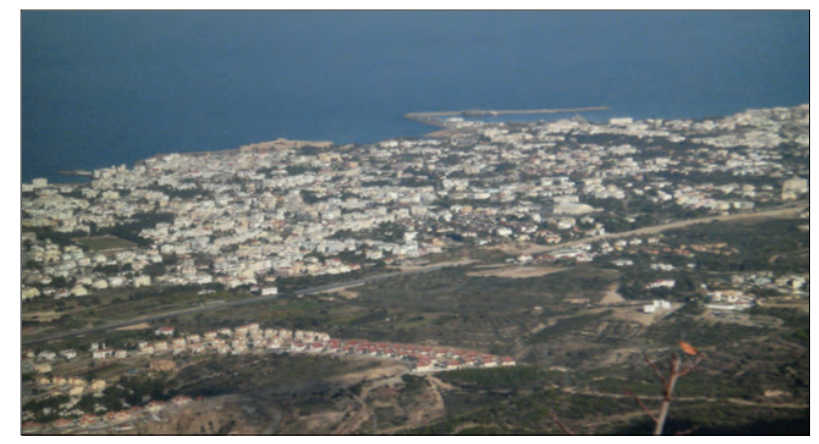

Figure 3. Urban Sprawl of mass construction in the City of Girne [10].

\section{Literature Review}

\subsection{An Overview of Girne-Cyprus}

North Cyprus is located at the intersection of three continents, and it is in the furthest East in the Mediterranean and far from Turkey, just 40 miles. These are many stories about the founders of Girne city (North Cyprus, 2020). It was said that Achaeans established the city of Girne when they came from the Peloponnese around the 10th Century BC, and others say that the Phoenicians founded it around the 9th Century BC[11]. 
In the 7th Century, the Byzantines protected Girne city, and they built the original Kyrenia Castle, which was extended by the Lusignans [11]. Under the Ottomans Empire, Girne stayed a secondary port. The British made a harbor and seaport, which made Girne a resting place, so the town became a resting place for ex-patriots and their families[11].

One can notice the many cultures and societies that lived and still live in North Cyprus, and this gave it multiple styles of architecture, but the most shown architectural style is from the Ottomans and the British colonies.

\subsection{An Overview of Globalization}

The human knew at the end of the last century new terms and concepts in politics, economy, and ideology, and these terms made the human mind facing difficulties meditate in it, which make it challenging to make it understood[13]. The term "Globalization" is one of the latest terms that have been defined by societies, which took attention from many researchers and thinkers trying to develop and explain the meaning of this term. Despite these attempts, the concept still has ambiguity as a problematic issue and an argument subject among people worldwide. Perhaps the reason for this difference as some see it because of the capacity of expressions in word and confusing concepts like planetary and global, international[13].

The urban areas of North Cyprus are going through massive changes and development, such as the addition of mass housing projects that are being expanded in the region[7]. These mass housing projects are being established not only in North Cyprus but all around the world. Unfortunately, this mass building process is changing the architectural and design identity of the country, which influenced the identity of the cities. Also, socio-cultural, social, physical changes in the city's context can change the fashion and lifestyle of the people[7].

Through the past decades, several cities' urban identity has been changing due to several reasons[7]. One of the important reasons that impact the architectural and design identity is the global construction industry and relying on importing building materials and construction styles that would drastically change the place identity.

Globalization is considered a discussion of the knowledge that improves awareness of the connections between different life scales [14]. According to the United Nations, globalization might be defined as a set of social, economic, technological, political, and cultural structures and methods appearing from the production's changing elements [14]. The different definitions highlight the different perspectives of globalization between the government, corporations, and individuals[15]. However, globalization has several impacts and sectors ranging from economic aspects, technological aspects, political aspects, and cultural aspects that may be intimately mixed. These aspects are essential factors of an individual's quality of life[16]. One can understand from the previous definitions that globalization has a part and aspects related to it. We can consider that globalization aspects are divided into economics, politics, and the environmental and architectural character.

\section{Research Methods}

This article's main aim is to discuss the impact of globalization on the architectural and design style in Girne-Cyprus. The information used in this article is obtained from articles and databases about the same issue. The article's methodology consisted of analyzing the urban sprawl and the new architectural and design styles that are replacing the traditional urban identity of Girne. Kyrenia (Girne) is facing a massive problem with the urban sprawl due to mass housing projects with the recent interest of international students coming and living in it for studying in several higher education institutions located in Girne and around North Cyprus. The methodology followed in this research is to document and observe the changes that are happening to Girne's identity.

The importance of this study is to increase awareness and strengthen the cultural identity of architecture and design that highlights the identity as a unique feature, regardless of the used architectural style. One can understand globalization's effects by observing how the new buildings are expanding and taking away the traditional local building.

\subsection{Aspects of Globalization Impacting Girne}

\subsubsection{Economic Aspect}

According to Brady, Beckfield, and Seeleib-Kaiser[17], economic globalization results from many reasons; the first one is about the large extending of modern production technologies around the world. Therefore, making the production corporations sure that the product is being sold everywhere, and that makes productions across the borders between countries, makes the world like an open market. The second reason is extending manufacturing branches worldwide by the same brand name with considering the costs of labor and producing the same quality everywhere. Finally, the trade limits will disappear because of economic globalization, allowing corporations to cross the national borders between countries[17].

Economic globalization can be observed in Girne in several places like downtown, main streets, and industrial areas. Economic globalization can be observed through the presence of international brands of clothes (Levis, United Colors of Benetton), sports equipment (Adidas, Nike), restaurants (Shooters, Gloria Jean's), and even car brands (Mercedes, Peugeot, Suzuki). This shows how these 
corporations are extending and expanding in Girne, and it is opening the way for other corporations to be added to the city's urban context. The economic aspect of globalization is affecting Girne's architecture by bringing International corporations to it, and most of these corporations have their building style, so by these different brands and corporations [9].

\subsubsection{Political Aspect}

According to the United Nations, political globalization is the invention of an international government that manages the relationships between the world nations and ensures the rights which come from social and economic globalization[14]. One of the results of political globalization is open trade policies. This can be seen in Girne through the regulations that make starting a business or buying a property process less complicated. This shows that these regulations protect foreigners' ownership, even if it is affecting the urban identity[18].

The political aspect of globalization can be observed in Girne from some regulations, which allow for foreigners to buy and have the ownership of properties in Northern Cyprus and these people are making some changes in their houses or building according to several styles and identities, and this creates different and international styles of architecture in Girne.

\subsubsection{The Environmental and Architectural Aspect}

The built environment is concerned about all the surrounding space around the people, and its focus on the relationship between humans and the environment (Butterworth, 2000). According to Mart and Alier [19], most of the environment's problems because of the international corporations because these corporations do not consider the ecological aspects of the environment during the production process[19].

During history, one can understand how architecture has played leading roles in human development, which we can see now as developed cities[20]. In the ancient communities, we can see the harmony between the social environment and the built environment. Still, nowadays, in the time of globalization, we can see significant opposition between the social environment and the cities in which humans made it [21]. Because of the globalized trend, communication, transportation, and information, we can see how these globalized elements affected urban planning and architectural design by making them like each other more and more[21]. The globalization effect of Girne's urban context can be observed through:

1. The unqualified spacing between buildings, Lack of space from the buildings to the road is due to the new building style that is being created to make use of the land as possible instead of thinking of the building's surroundings.

2. Conversion of traditional buildings to other uses different from the original purpose, such as tearing down traditional residential buildings to create space for more commercial buildings

3. The new buildings introduced are out of scale and different from traditional buildings in terms of size, height, and form[12].

Also, previous research has found that new mass housing units that are being added to the Girne's land are going into modifications to be more adaptive to the city's original design identity. Those changes are in the form of increasing clear views and transparency amongst the indoor spaces and increasing transparency between the indoor and outdoor spaces to emphasize open space as it relates to the traditional buildings in Cyprus where had the concept of the open courtyard (see Figure 04)[8]. Moreover, enclosing the space in front of the entrance and Enclosing the balcony to have more privacy[8]. Furthermore, it was found that people tend to enlarge the balcony on the upper floor to have better views and divide the living room into two subspaces to have better privacy if the owner has guests[8].

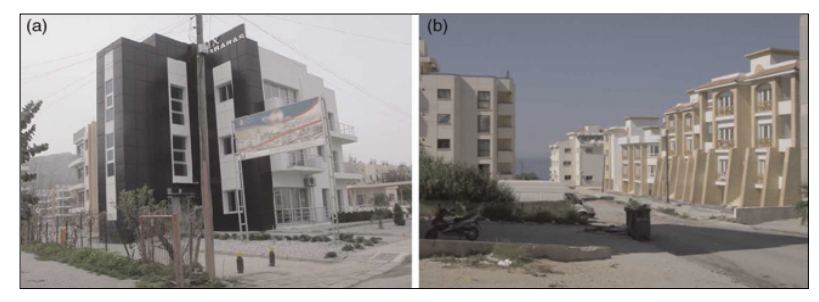

Figure 4. New Architectural Styles Spreading throughout North Cyprus[12]

\section{Discussion and Conclusion}

Through analyzing the controversies surrounding the architectural and design identity of Girne City, this study shows that the international new construction sector that emerged to Girne, along with the open mass housing that drives the production of new and global architectural and design projects in Girne city. The problem between being open to the emerging architectural and design styles and global consumerism will lead to creating a new architectural and design fabric of Girne city and losing the unique architecture and design from the past. The case study of Girne city disseminates the rationale search for global attention to Girne's city at the expense of the traditional architecture, as well as its mixed consequences and effects on local cultural elements.

After discussing some of the globalization aspects, which are economic, political, and environmental ad architectural, from Girne's perspective, we can observe that Girne is slowly being affected by globalization. These changes can be observed in the new architectural styles that are being introduced to the city (see figure 01). We can understand that each aspect of globalization is affecting the architecture in Girne in some way. Still, the result is almost 
the same in each element, and the result is affecting the architectural style and the place identity.

The argument of this article is in line with previous research, which found that the new construction types that are being newly added to the urban context of the city are not as accepted by the community, and it is believed that is changing the urban identity of the city[22].

Also, it was found the global tourism, which is targeting Girne city, is negatively impacting the city were previous research found that there are significant differences between the city's historic architectural and urban identity and the newly developed areas where new construction styles are being added to the city[12].

In this research, we have examined the critical topic of the impact of globalization on the architectural and urban heritage of the city of Girne in Northern Cyprus, which has recently gained lots of interest due to its prominent location as a tourist destination, higher education destination, and investment destination for construction companies. In the globalization era we are currently living in, large varieties of new construction and architectural styles are being added to the city rapidly, and within them lay substantial changes and patterns that are being added to the city's fabric [23]. Hence, this can be seen in the out of context design and architecture that can be observed throughout the city. In this review of existing research, it was found that this attitude toward globalizing the city's architectural and urban style is negatively impacting the city's urban and architectural identity, and it will make the city lose its identity over the years to come. Having such information earlier would leverage the local business and government to regulate mass housing and building to keep the place identity, making Girne a unique place to live, work, visit, or study in.

The impact of globalization in relation to the architectural and the urban style of Girne was discussed in this article. Girne city was presented in this research as a case study of a bigger problem that may be reflected in several cities around the world, and it has been studied as a case study to refer to the topic of globalization's impact on urban form. It can be concluded that the existing situation was mass housing and construction companies that are being introduced to the city will increase the urban growth and development of the Girne. However, this development will directly reflect on the architectural and urban form of the city negatively. If the same attitudes keep developing, even more, the city's identity will be lost.

The construction industry in North Cyprus is an engine driving economic growth and development. However, unlike other countries where the construction industry is driven by local architecture, North Cyprus is being approached by international and global architectural styles. The paradox of local identity and the urge to embrace international and global architecture and design styles illustrate the changing relationship between global architectural style and local architectural identity due to globalization's impact.

Therefore, the government body should protect the local identity by promoting traditional architecture and design and the appropriate development and land use. Also, there should be legal planning regulations that are adequate and appropriate to guide the construction sector in a way that to keep, maintain, and preserve the traditional and historical identity of the city[10].

The results of this research indicated that there is a drastic change in the identity of architecture and design in the City of Girne. Therefore, architects, interior designers, and lawmakers should pay more attention to the design styles they are developing for the city to maintain its architectural identity and heritage.

\section{REFERENCES}

[1] X. Ren, "Architecture and nation-building in the age of globalization: Construction of the national stadium of Beijing for the 2008 Olympics," Journal of Urban Affairs, vol. 30 , p. 2, 2008.

[2] N. B. Hartanti and W. Martokusumo, Street Network Planning and Changing Urban Identity in Bogor City Center. ITB Indonesia: In Proceedings of Planocosmo International Conference, 2013.

[3] V. Navarro, "Comment: whose globalization?" American Journal of Public Health, vol. 88, no. 5, pp. 742-743, 1998.

[4] C. Jamieson, the Future of Identity in Architecture and Urbanism. RIBA Building Futures, 2009.

[5] M. Riza, N. Doratli, and M. Fasli, "City branding and identity," Procedia-Social and Behavioral Sciences, vol. 35, no. 293-300, pp. 723-745, 2012.

[6] V. Yorucu, "Construction in an Open Economy: Autoregressive Distributed Lag Modeling Approach and Causality Analysis Case of North Cyprus," Journal of construction engineering and management, vol. 139, no. 9, pp. 1199-1210, 2013.

[7] M. Celikag and S. Naimi, "Building construction in North Cyprus: problems and alternatives solutions," Procedia Engineering, vol. 14, pp. 2269-2275, 2011.

[8] H. Pulhan and H. Orcunoglu, No Title. Designing houses for change: understanding of changes in mass housing developments in the city of Girne (North Cyprus, 2005.

[9] N. Ozay, "A comparative study of climatically responsive house design at various periods of Northern Cyprus architecture. Building and Environment", vol. 40, no. 6, pp. 841-852, 2005.

[10] Hoskara, Z. Legal Frameworks and Housing Environments in North Cyprus, vol. 26, p. 1, 2009.

[11] M. Altinay and K. Hussain, Sustainable tourism development: a case study of North Cyprus. International Journal of Contemporary Hospitality Management, 2005. 
[12] B. O. Vehbi and N. Doratli, "Assessing the impact of tourism on the physical environment of a small coastal town: Girne, Northern Cyprus," European Planning Studies, vol. 18, no. 9, pp. 1485-1505, 2010.

[13] Prasad, S.K., Rachna, J., Khalaf, O.I., and Le, D.-N. Map matching algorithm: Real-time location tracking for smart security applications. Telecommunications and Radio Engineering (English translation of Elektrosvyaz and Radiotekhnika), 2020, 79(13), pp. 1189-1203

[14] R. Al-Rodhan, N. R., and G. Stoudmann, "Definitions of globalization: A comprehensive overview and a proposed definition," in Program on the Geopolitical Implications of Globalization and Transnational Security, 6. Altinay, M., \& Hussain, K. (2005). Sustainable tourism development: a case study of North Cyprus. International Journal of Contemporary Hospitality Management. Berger, 2006, pp. $1-21$.

[15] Khalaf, O. I., \& Abdulsahib, G. M. (2019). Frequency estimation by the method of minimum means squared error and P-value distributed in the wireless sensor network. Journal of Information Science and Engineering, 35(5), 1099-1112

[16] W. I. Robinson, "Globalization and the sociology of Immanuel Wallerstein: A critical appraisal," International Sociology, vol. 26, no. 6, pp. 723-745, Nov. 2011.
[17] D. Brady, J. Beckfield, and M. Seeleib-Kaiser, "Economic globalization and the welfare state in affluent democracies, 1975-2001," American Sociological Review, vol. 70, no. 6, pp. 921-948, 2005.

[18] S. Berger, "Globalization and politics," Annual Review of Political Science, vol. 3, no. 1, pp. 43-62, 2000.

[19] J. Mart and U. Alier, The Environmentalism of the Poor: A Study of Ecological Conflicts and Valuation. Publishing: Edward Elgar, 2002.

[20] L. Farrelly, The fundamentals of architecture. Bloomsbury Publishing, 2012.

[21] I. M. Eldemery, "Globalization challenges in architecture," Journal of Architectural and Planning Research, pp. 343354, 2009.

[22] N. Cyprus, "Retrieved 18 February 2020, from Oktay, D., \& Bala, H," A. (, vol. 9, no. 2, pp. 201-215, 2020.

[23] V. Yorucu and R. Keles, "The construction boom and environmental protection in Northern Cyprus as a consequence of the Annan Plan," Construction Management and Economics, vol. 25, no. 1, pp. 77-86, 2007. 